Paraguay and the Triple Alliance:

The Postwar Decade, 1869-1878 
THIS PAGE INTENTIONALLY LEFT BLANK 
Latin American Monographs, No. 44 Institute of Latin American Studies The University of Texas at Austin 
THIS PAGE INTENTIONALLY LEFT BLANK 


\section{Paraguay and the Triple Alliance The Postwar Decade, 1869-1878}

by Harris Gaylord Warren with the assistance of Katherine F. Warren 
International Standard Book Number 0-292-76444-8 (paper)

0-292-76445-6 (cloth)

Library of Congress Catalog Card Number 77-075824

Copyright (C) 1978 by Harris Gaylord Warren All Rights Reserved

The Latin American Monographs Series is distributed for the Institute of

Latin American Studies by:

University of Texas Press

P. O. Box 7819

Austin, Texas 78712 
To the memory of

two great Paraguayan scholars

Efraím Cardozo

and

Pablo Max Ynsfrán 
THIS PAGE INTENTIONALLY LEFT BLANK 